\title{
GRAMMATICAL EXPRESSION OF BUGIS POLITENESS
}

\author{
Murni Mahmud
}

\begin{tabular}{c} 
Email: dwimurnye@yahoo.com \\
Fakultas Bahasa dan Sastra Universitas Negeri Makassar \\
Alamat Korespondensi: Taman Arthalia B3 No. 4 Makassar Jln Dg Tata Parangtambung \\
\hline
\end{tabular}

\begin{abstract}
This paper discusses the use of grammar as a strategy to express politeness in Bugis society. This is based on the research I conducted in 2005 in two different Bugis communities: the first was in Awangpone, a rural area and the second was in Parepare. There are three main aspects of Bugis grammar used by Bugis people to encode their politeness. The first one is the pronoun system, in which Bugis speakers use idi', ta-, or -ki, (the $1^{\text {st }}$ plural inclusive pronoun) to address people politely rather than using iko, mu-, and $-n u$ (the $2^{\text {nd }}$ person pronoun). The second one is the use of participant avoiders such as passive voice di- or terms such as tauwé 'people' or anu 'something or someone' to avoid mentioning the subject or object directly. Another device is the phonological alternations between final $-o$ and final $-i /-e$, in which final $-o$ is less polite than final $-i /-e$ such as the pairs iyé'/iyo 'yes' or -mi/-mo 'just'.
\end{abstract}

\section{Keywords}

Politeness, Bugis People, Grammar, Pronouns, Phonological Alternation, Participant Avoiders

\section{Introduction}

Many scholars have conducted research on politeness and they mostly associate politeness with its functions in conversational interactions in a particular society (Brown and Levinson 1987, Mizutani and Mizutani 1987, Pizziconi 2003).

Politeness is defined in different ways such as a kind of 'rational, goal-oriented behaviour' (Haverkate, 1988), 'politic behaviour' (Watts, 1992:50), 'appropriate behaviour' (Meier, 1995), 'a diplomatic strategy of communication' (Kummer (1992:325), and 'etiquette' (Geertz, 1960). Other terms, such as 'honorification' or 'honorific', are used in reference to politeness (Scupin, 1988; Agha, 1994).

Lakoff (1976:64), for example, interprets politeness as 'forms of behaviour which have been developed in societies in order to reduce friction in personal interaction'. She proposes two basic rules for politeness, which she calls rules of pragmatic competence: 'be clear' and 'be polite'. Furthermore, Lakoff formulates the following rules of politeness as 'formality: keep aloof, deference: give options, and camaraderie: show sympathy' (1976:65). Holmes (1995:4-5) describes politeness as 'behaviour which is somewhat formal and distancing, where the intention is not to intrude or impose'. According to her, 'being polite means expressing respect towards the person you are talking to and avoiding offending them.

Politeness is culture specific as, like all communicative acts, it carries different meanings in different cultures and it will also vary depending on certain circumstances. What is regarded as linguistically polite behavior in one culture might be considered impolite behavior in another culture. Zhan (1992:3) notes that 'politeness strategies vary from language to language, from culture to culture.' Hongladaron and Hongladaron (2005:159) also note that 'politeness is a culturally embedded notion both relates to human culture and to the various local cultures'.

Therefore, it is interesting to explore politeness practices in different communities such as in Bugis society. Bugis people who are mostly found in South Sulawesi Indonesia have been long known for their unique traditional and religious norms. Their concept of pangngaderreng 'a system of conduct', siri' na pesse 'shame and compassion', and the symbolism of sarung sutra 'silk sarong' characterized their cultural life. In addition, their religious norms and other social systems such as gender and social status 
contribute to these characteristics (Abdullah 1986, Pelras 1996, Mahmud 2008a).

In expressing their politeness, Bugis people use various strategies such as grammar, address terms, speech levels, code switching, jokes, humor, and small talk (Mahmud, 2008a, 2008b). One of the strategies is the use of grammar. This paper is going to explore the use of these grammatical expressions by Bugis people in order to be polite.

\section{Method}

The data for this paper were partly taken from my Ph.D thesis, which was based on the fieldwork that I conducted for one year in 2005 in two different Bugis communities, one is in the rural area, Awangpone, Kabupaten Bone, and another is in the urban area, Parepare.

To collect data, I employed ethnography of communication using some strategies such as participant observation, informal interview, and recording conversations. Two groups of respondents were involved in this research. The first group was interviewed about the concept of politeness. They included adat 'cultural' leaders, religious leaders, and professional workers aged from 23 to 73 years old, both men and women. The second group of respondents was those whose conversations were recorded. There were 241 respondents: 136 respondents from Awangpone and 105 from Parepare

To obtain spoken Bugis language, I recorded a variety of conversations between men and women using tape recorders in three contexts: single-sex settings (male and male or female and female) and mixed-sex settings (female and male). Conversations were recorded in formal settings such as in offices and schools and in informal settings such as in families and neighbourhood. Participants were housewives, graduate students, office workers, and teachers aged 15 to 50 years old.

\section{Discussion}

There are three important sets of grammatical aspects of Bugis politeness. They are pronouns, participant avoiders, and phonological alternations.

\section{Pronoun Systems}

The first important aspect of Bugis grammar that is used to show politeness is the pronoun system. In Bugis conversations, pronouns used are mostly from Bugis, but some Indonesian pronominal terms are used as well. The Bugis pronouns can be seen in the following table:

Table 1

Pronouns used in Bugis language

\begin{tabular}{|c|c|c|c|c|c|}
\hline $\begin{array}{c}\text { Pronou } \\
\text { ns }\end{array}$ & $\begin{array}{c}\text { Indepe } \\
\text { ndent } \\
\text { Pronou } \\
\text { n }\end{array}$ & $\begin{array}{c}\text { Ergat } \\
\text { ive } \\
\text { Pron } \\
\text { oun }\end{array}$ & $\begin{array}{c}\text { Absolu } \\
\text { tive } \\
\text { prono } \\
\text { un }\end{array}$ & $\begin{array}{c}\text { Posses } \\
\text { sive } \\
\text { Pronou } \\
\text { n }\end{array}$ & $\begin{array}{c}\text { Meanin } \\
\mathrm{g}\end{array}$ \\
\hline $\begin{array}{l}1^{\text {st }} \\
\text { perso } \\
\text { n sg } \\
\end{array}$ & $I y a^{\prime}$ & $-k a^{\prime}$ & $u-$ & $-k u^{\prime}$ & $\begin{array}{l}\mathrm{I} / \mathrm{me} / \\
\mathrm{my} / \mathrm{mi} \\
\text { ne }\end{array}$ \\
\hline $\begin{array}{l}2^{\text {nd }} \\
\text { perso } \\
\mathrm{n} \\
\end{array}$ & Iko & $-k o$, & $\begin{array}{l}n u-, \\
m u-\end{array}$ & $\begin{array}{l}-m u /- \\
n u\end{array}$ & $\begin{array}{l}\text { You/yo } \\
\text { ur/you } \\
\text { rs }\end{array}$ \\
\hline $\begin{array}{l}3^{\text {rd }} \\
\text { perso } \\
n\end{array}$ & Aléna & $-i$ & $n a-$ & $-n a$ & $\begin{array}{l}\mathrm{He} \\
/ \mathrm{h} \\
\mathrm{im} \\
/ \mathrm{h} \\
\text { is } \\
\text { or } \\
\mathrm{Sh} \\
\mathrm{e} / \\
\text { he } \\
\mathrm{r} \\
\text { or } \\
\text { It/ } \\
\text { its }\end{array}$ \\
\hline $\begin{array}{l}1^{\text {st }} \\
\text { perso } \\
\text { n pl } \\
\text { incl }\end{array}$ & Idi' & $-k i^{\prime}$ & ta- $/ i^{-}$ & $-t a^{\prime}$ & $\begin{array}{l}\text { We/ou } \\
\text { r/us/o } \\
\text { urs }\end{array}$ \\
\hline
\end{tabular}

Although the second person forms are sometimes used to address others, it is usually seen as more polite to address people using the first person plural inclusive forms (idi',-ki', ta-/i-) rather than the plain second person forms (iko,-ko, nu-/mu-). The use of the first person plural inclusive possessive pronoun ( $\left.-t a^{\prime}\right)$ is also more polite than the second person possessive pronouns $(-n u /-$ $m u$ ). The use of polite pronouns (idi',-ki', ta-/i-) are more distant or formal whereas the less polite pronouns (iko. $-k o, n u-/ m u-$ ) are more familiar and informal.

These pronouns are exploited by Bugis people in order to express their politeness. Due to the influence of power in the form of hierarchical social status, the use of different pronouns to address different people in Bugis society is also heavily based on social status. This is similar to the use of pronouns of 'power and solidarity' as proposed by Brown and Gilman (1972:255-277).

According to them, there are two types of pronouns as politeness devices. The first type is pronouns of power which is non-reciprocal or asymmetrical, with the greater receiving 
solidarity and the lesser intimacy. The second type is pronouns for intimacy and solidarity, which is reciprocal or symmetrical In other words, reciprocal use of pronouns implies solidarity and mutual respect while nonreciprocal relates to power and status. Some examples are given below to show how pronouns are used differently by different people in different situations in Bugis society.

\section{Extract 1: Suggestion to talk}

Two female speakers of a similar age and status, who are close relatives and neighbours, Puang Aji Masi (PAM, 50) and Puang Aji Semma (PAS, 50) were talking. Both of them are hajj and noble. PAS did not know what to talk about as I recorded them and PAM suggested talking about the time she went to Cempalagi, a hamlet in Mallari.

PAS: $\quad$ aga lo' ubicara?

'what should I talk about?'

PAM: awwé, akkedako poléna'Cempalagi

'awwé, you say I have just come from Cempalagi [a hamlet in Awangpone]'

In the above extract, PAM used the second person pronoun -ko in akkedako instead of the first plural inclusive pronoun -ki' in akkedaki'. This direct use of the second person -ko by PAM to PAS is acceptable because the interlocutors are of similar status and are close relatives and neighbours. This familiarity encouraged PAM to use the familiar pronoun - $k o$.

\section{Extract 2: Asking a female fish seller}

PAM was talking to a female of similar age but different social status, Hunaeda $(\mathrm{H}, 50)$, a commoner without any hajj or noble status. Hunaeda was selling shrimps and prawns to PAM and other females: Puang Aji Semma (PAS, 50) and Puang Mari (PM, 50).

\section{PAS: magi Hunaeda?}

'what's the matter with it [i.e. you], Hunaeda?'

$\mathrm{H}: \quad$ nulléna

'how can this be'

PAM: nulléna. Balaceng ibalu'

'how can this be? [We] sell shrimps'

$\mathrm{H}: \quad$ lo'ki' melliwi?

'are we [i.e. you] going to buy some?'

PM: déto 'not really'

PAM: tassiawaé' loppanutu?

'how much is a cup of those prawns of yours anyway?'

$\mathrm{H}: \quad$ duwa sitengnga, Aji

'two and a half [two thousand five hundred rupiahs], Aji'

Although they are familiar as close neighbours, are of similar age and have been friends since a young age, the different status PAM has as hajj and noble encourages the non-reciprocal use of pronouns. PAM used the familiar possessive pronoun $-n u$ when she was asking about the price of the prawns, tassiawaé loppanutu? 'how much is a cup of those prawns of yours?'. Conversely, Hunaeda used the distant pronoun $k i$ ' in lo'ki' melliwi? 'are we [i.e. you] going to buy some?'. This shows the asymmetrical relations among the interlocutors are influenced by their status differences.

\section{Extract 3: Asking an older fisherman}

PAM was talking to Mardi (M, 65), an older fisherman without any hajj or noble status. She was asking about Mardi's daily activities as a fisherman.

PAM: dé muno' tasi'é?

'didn't you go to the sea [fishing]?'

M: ba, polémuwa..'

'yes, I have been..'

PAM: dé'ga muwala?

'didn't you catch anything [fish or any other seafood]?'

M: $\quad$ kamuwa na..

'yes [there are] some but..'

PAM asked Mardi using the familiar pronoun $m u$ in all of her questions above: dé' muno' tasi'é 'didn't you go to the sea [fishing]?' and déga muwala? 'didn't you take anything [fish or any other seafood]?'. Like extract 2 above, this extract also shows an asymmetrical relation between the speakers influenced by their status differences. Although Mardi is older, and male, because of the high status of PAM, Mardi was addressed using the familiar pronoun. Compare this with extract 4 below:

\section{Extract 4: The mosque donation}

PAM was talking to an older male with high status since he is a hajj and noble, Puang Aji Akil 
(PAA, 64), who is also a close relative and neighbor. At the time, they were talking about the money owned by the mosque.

PAA: ko mabbicara makkeda iya malamanengngi, tappa uti' maneng lao masigi'é

'if [someone] accused me of taking all [the money], then I would take [the money] directly to the mosque'

PAM: iti' maneng lo'ka masigi'é?

'we [i.e. you] took all [the money] to the mosque, didn't we [i.e. you]?'

PAM used a polite device $i$ - in $\underline{i} t i^{\prime}$ instead of using $m u$ - in $\underline{\text { muti' }}$ which would have been expressed in the utterance: muti' maneng lokka masigi'é. This extract shows the use of the first person plural inclusive agent marker as a generic marker, where no direct reference to a first person agent is entailed. It is used to refer to a second person agent, PAA, and it made her more distant and polite. This extract also shows that although both speakers are familiar, being close relatives and neighbours and have similar status as hajj and noble, pronoun choice is influenced by age and sex differences.

Therefore, PAM used familiar pronouns and distant pronouns to different interlocutors. The first important aspect is familiarity. Talking to a speaker who is closely related and a neighbour as well as being a similar age and status encouraged her to use familiar pronouns. With Hunaeda in extract 2, PAM also used a familiar pronoun. In her conversation with Mardi in extract 3 , status seem the main determinant because Mardi is older and a male. When she was talking to PAA in extract 4, she used different pronouns. Although PAA was also her close relative and neighbour and has a status as high as PAA as hajj and noble, she uses the more distant pronoun because PAA was an older male with high status.

Beside the use of Bugis pronouns as indicators of politeness, Bugis people also use Indonesian pronouns due to the fact that Bugis people are bilingual. The examples can be seen below:

\section{Extract 5: School boys at home}

School boys of the same age were talking to each other at home about their school farewell party. They had just finished their final exam. Amin (A, 15)'s farewell party is different from others as he is from an Islamic school. His school only invited kasidah 'a kind of religious performing group', not a band, playing modern pop music.
I: adakah band kau ambil?

'are you taking a musical band [in the farewell party]?'

A: ndak ada band. Kasidahji kalau perpisahan

'no [musical] band. It is just kasidah [a type of Islamic music] for the farewell party [in my school]'

In the first turn, Illa (I, 15) asked using the familiar Indonesian pronoun kau. However, the use of this pronoun is acceptable because of their familiarity as friends and similar age and status.

Bugis speakers may also use the Indonesian pronoun Anda. This pronoun is more impersonal and used to refer to a general audience, possibly someone unknown for speakers of the same age as or younger than the speaker Sneddon (1994:161).

\section{Extract 6: A lecturer and his student}

A lecturer and a student: Haji Iksan (HI, 38) and Akmal (A, 21) were talking on the campus. Akmal wanted to conduct some training for his fellow students. He was asking about his lecturer's ability to donate some funds. HI asked him to explain his reasons so that he could decide whether to contribute or not.

\section{HI: $\quad$ anda mau bikin kegiatan apa? \\ 'what kind of activity are you going to do?' \\ A: kegiatan pelatihan kader dasar tingkat lanjutan-nya \\ 'a follow-up activity of basic candidate training'}

Despite his position as Akmal's lecturer, $\mathrm{HI}$ in the last turn used Anda to address Akmal. This created a more distant and formal relation between the interlocutors. This is influenced by the formality of the situation in the setting or the locations of the recordings, although $\mathrm{HI}$ is older and higher in his status than Akmal.

Other Indonesian pronouns used by Bugis speakers are kita and kami. The pronoun kita is the first inclusive plural pronoun and means 'we' where the person being spoken to is included, that is 'I and you'. The other is the first exclusive plural pronoun kami, which means 'we' where the person being spoken to is excluded, that is 'I and others but not you' (Sneddon, 1994:160).

Due to the influence of bilingualism, Bugis speakers, especially in the urban area may use these Indonesian pronouns, which do have Bugis equivalents, especially kita. This pronoun kita has 
the same meaning as the first Bugis plural inclusive pronoun idi'. Kita is used to mean 'you' by many speakers in South Sulawesi, not only by Bugis, but also by other ethnic groups such as Makassar, Mandar, and Toraja. When speaking Indonesian, speakers sometimes used kita to address other people in order to be more polite. Indonesian pronouns such as kamu/kau to mean 'you' are considered impolite and familiar. Using idi' or kita to address people is more polite than saying iko or kamu 'you'. Examples can be seen in the following extracts:

\section{Extract 7: A husband and a wife}

A husband and a wife in a family in Parepare were speaking to each other. The wife, Wardah $(\mathrm{W}, 49)$ asked her husband, Gaffar $(G, 52)$ why he hadn't gone to school. At the time, it was already 10 o'clock in the morning.

\section{W: iih..Pak! kenapa kita tidak, tidak pi sekolah?}

'iih [how come], Pak! Why didn't we [i.e. you], didn't we [i.e. you] go to the school?'

G: $\quad$ ndak-ndak aktif tonji juga sekolah

'not- the school is not active yet'

W used Indonesian, and to be polite, she used the first plural inclusive Indonesian pronoun kita to address her husband kenapa kita tidak 'why didn't we [i.e. you]'. These pronouns can also be used in formal settings, as seen in extract 8 below:

\section{Extract 8: A visit to Sub-District office}

Pak Haris $(H, 54)$ was talking to the head of subdistrict office, Pak Latif $(L, 55)$ in a formal setting. He was asking if Pak Latif could accompany him to Bulu Aroang, an important historical location in Parepare, which is under Pak Latif's authority.

\section{$\mathrm{H}: \quad$ ada yang menemani kita ke sana}

'there is [a person] accompanying us to get there'

L: iyé, siapa tahu Pak, kalau anu kita hubungan juga anu POM di sana

'yes, who knows Pak, if we [i.e. you] contact with POM [Polisi Militer-Military Police] there?'

Pak Haris asked using kita instead of kami to include all of the speakers, which is more polite and formal. In responding his request, Pak Latif also used kita instead of kau/kamu to be more polite in his response to Pak Haris. Indeed, the use of an address term Pak without mentioning the name of Pak Haris also made him more polite.
The formality of the situation and their distant relationship led both speakers to use formal and more polite pronouns.

Bugis speakers, especially in the urban area, may also use Bugis pronouns within Indonesian utterances which may indicate level of politeness as seen below:

\section{Extract 9: A research assistant}

HE was talking to Marwiah (W, 27) about my need for a research assistant. They are both high school teachers and close friends. HE asked Marwiah if she was available to become my research assistant and discussed the payment for her.

HE: ajukanki' bédéng penawaran brapa mau dibayarki'?

'we [i.e. you] make a request anyway, how much are we [i.e. you] going to be paid?'

W: (to Haji Erna and me) wéé, kak! Janganmi..

'kak [older sister!]! there is no need [to be paid]'

HE asked Marwiah to say how much salary she wanted for each month as my research assistant. She used the Bugis pronoun ki' in ajukanki' and dibayarki in her mainly Indonesian. Although both speakers are friends, and HE was senior in age and status, she used distant pronouns. This was influenced by my presence as a researcher; the conversation was directed to me. The Bugis pronoun $-k i$ ' added to her Indonesian made HE's speech more distant and more polite. Even in more formal settings, Bugis pronouns can be mixed with Indonesian to make speech more polite.

\section{'Participant Avoiders'}

A second aspect of Bugis grammar that can be exploited for showing politeness is the use of 'participant avoiders'. One of these is the use of passive rather than active forms of the verb. Using a passive form marked by the passive prefix $d i$ - and $r i$ - can free the speaker from having to mention a participant overtly at all. According to Lakoff and Ide (2005:8), passive forms can be used to 'deny responsibility for the propositions we are uttering'. See extracts below:

\section{Extract 10: The school party}

Aslinah was still asking Minah about what to buy for their school party (see extract 8 above).

A: aga lo' $\underline{\text { dielli? }}$ 
'what is going to be bought [what are you going to buy]'

M: hm?

A: aga lo' taelli?

'what are we [i.e. you] going to buy?

M: béppa

'cakes'

The words: dielli and taelli? above are polite expressions in Bugis society. Aslinah (A, 30) asked Minah (M, 30), aga lo' dielli 'what are you going to buy [i.e. what is going to be bought?]' which was then repeated, aga lo' taelli 'what are we [i.e. you] going to buy'. In the first turn, Aslinah used a passive verb di- in dielli 'to be bought' without referring to any participant. Use of active verbal forms requires at least pronominal reference to a participant, but passives avoid the need to refer to any participant. Later, she mentioned the participant by saying taelli 'we [i.e. you]' when she needed to rephrase the question more directly. As noted in the previous section, the use of the first plural inclusive pronoun $t a$ - indicates politeness. The formality of the situation encouraged Aslinah to use these polite devices despite the similar age and status of the addressee.

Another participant avoider is use of the term people. By saying people, the real subject or the participant is avoided. The example is as follows:

\section{Extract 11: At Safari Ramadan}

Some males were coming from the mosque praying. At the time, there were many guests sitting in the lounge room and it is not polite to pass through. Therefore, those males went through the kitchen where many females were sitting and preparing meals.

S: (to some males coming through the kitchen) tama'ni mai pa' massotingngi tauwé@@

'come here inside because the people [the researcher] are shooting'

Ah: magai?

'what's the matter?'

Sa'di' (S, 46) commented on me who was doing a recording with my video camera. She said, tama'ni mai pa' massotingngi tauwé@@ 'come here inside because the people [the researcher] are shooting'. She did not mention me directly; rather she said tauwé 'the people' to politely refer to me by not mentioning my name directly.
Speakers may use the term anu 'someone or something' to refer to a certain object or person indirectly or to avoid specifying the participant or the object. See extract 12 below:

\section{Extract 12: The school program}

Before starting the conversation, Pak Arif asked Haji Beddu's consent to record their conversations. Haji Beddu (HB, 60) tried to refuse to be recorded as he had something to do at the time. Pak Arif $(A, 49)$ still tried to continue the conversation and explained his reason.

HB: (refusing to be recorded) éé.. Ada anu to 'umm..there is something, isn't it'

A: tapi anu saja to, sekedar artinya ya perkenalan. Jadi kira-kira dengan.. bagaimana kita ini, Pak Aji éé.. tentang adanya, artinya adik kita dari STAIN ini.

'but it is only this, isn't it? Just an introduction. So, probably with..how about us, Pak Aji?, umm..with our younger brothers and sisters [students] from STAIN [Sekolah Tinggi Agama Islam Negeri-State College of Islamic Studies].

Both of them used anu to avoid mentioning the objects to make their speech less impolite in the presence of other newly met people in their school. This strategy avoids identifying the participants in an event and regard politeness. As with the choice of pronouns, their use is influenced by status of the interlocutors and the formality of the situations.

\section{Phonological Alternations}

There are also a number of pairs of semantically equivalent terms in which a phonological alternation between final $-o$ and final $-i /-e ́$ can be used to encode politeness differences in Bugis. Final $-o$ is less polite than final $-i /-e ́$. One of the examples is the use of iyé/iyo 'yes' which can function to strengthen arguments and soften disagreements. Compare these two extracts below:

\section{Extract 13. Expressing condolosence}

Two female teachers, Nur $(\mathrm{N}, 27)$ and Marliah (M, 27) are talking during the school break in their school. Nur was explaining the plans for the school. Nur asked her colleague, Marliah to visit their friend's house where there was to be a special gathering because of the death of Puji's husband some days ago. 
$\mathrm{N}$ : (asking whether Marliah had known the plan) waseng napedang mukki' Puang Aji?

'I thought we [i.e. you] had been told by Puang Aji [our headmaster], hadn't we?'

M: dé'..keda aga?

'no ..what did he say?'

$\mathrm{N}$ : (explaining the plan in the school) yéro lo'to dianu.

'that also needs to be done'

M: oh iyé', sekali dianu di'.. di..

'oh, yes, let it be done once.'

$\mathrm{N}$ : yessoé, ivé. yéro kubolana. Puang Aji mangngobbi'

'today, yes..that is in her [Puji]'s house. Puang Aji called'

Note that when Nur indicated the school plan, Marliah confirmed her availability and said iyé. Later, Nur explained again the reason by saying that it was their headmaster (Puang Aji) who had called. She also said iyé'. Although the speakers could also have used iyo, this would have been less polite. In this case, the use of iyé' 'yes' strengthens the agreement.

Another example of phonological alternations as polite devices is the use of the pair of aspect marking suffixes $-m i /-m o$ 'just', which refers to the immediacy of activities. Examples are seen in extract 14 below:

\section{Extract 14: Invitation to eat}

Two teachers: Lina (L, 29) and Rosida (R, 29), were serving cakes to me. Lina asked me to stop the recording and invited me to eat the cakes.

L: (asking me to stop videoing and start eating the cakes they served) Sudahmi soting dulu hé! Makanmidulu@@

'just stop shooting at the moment! just eat'

R: (asking me to eat cakes) Makanki' dulu kué 'we [i.e. you] try some cakes first'

Lina used the polite ending $-m i$ in sudahmi and makanmi rather than -mo in sudahmo and makanmo. Note that Rosida also was trying to be polite by using the first plural inclusive pronoun $-k i$ in makanki' rather than the second person pronoun $-k o$ in makanko.

\section{Conclusion}

This paper has discussed the use of some grammatical expressions by Bugis people to express their politeness. These can be seen from the use of pronouns, some aspects to avoid participants, and some phonological alternations. Analysis of the conversations shows that the more polite pronoun takes the plural form (the first inclusive pronouns such as idi', ta-,-ki') rather than the singular form (the second person pronouns iko, $m u$-, and -nu). Indonesian pronouns can be used when speaking Bugis, but to be more polite, the second person Indonesian pronoun. The discussion also shows the importance of avoiding participants by the use of terms such tauwa, anu, or the use of passive voice. In addition, some phonological alternations in which the ending $-o$ is less polite than $-e$.

Many factors influence the choices of these grammatical aspects. In both areas, factors such as age and status differences play important roles in determining the polite usage of those grammatical expressions. For example, the use of pronouns which was greatly influenced by different ages, status, and gender. Due to the influence of power in the form of hierarchical social status, the use of different pronouns to address different people in Bugis society is also heavily based on social status. The lower the status of the speaker is, the greater their tendency is to use very formal and polite pronouns. However, in some situations, other factors such gender, familiarity, and situation may contribute to the choice of Bugis politeness expressions.

\section{REFERENCES}

Abdullah, Hamid. 1985. Manusia Bugis Makassar: Suatu Tinjauan Historis Terhadap Pola Tingkah Laku dan Pandangan Hidup Manusia Bugis Makassar. Jakarta: Inti Idayu Press.

Agha, Asif. 1994. 'Honorification'. Annual Review of Anthropology, 23: 277-302.

Brown, Penelope and Stephen Levinson. 1987. Politeness: Some Universals in Language Use. Cambridge; New York: Cambridge University Press. 
Brown, Roger, and Albert Gilman. 1972. 'The Pronouns of Power and Solidarity.' In Giglioli, Pier Paolo (ed.). Language and Social Context. Great Britain: Cox \& Wyman Ltd, Reading, pp 252282.

Geertz, Clifford. 1960. The Religion of Java. Illinois: The Free Press of Glencoe.

Haverkate, Henk. 1988. 'Toward a Typology of Politeness Strategies in Communicative Interaction'. Multilingua, 74: 385-409.

Holmes, Janet. 1995. Women, Men, and Politeness. London and New York: Longman.

Hongladaron, Krisadawan, and Soraj Hongladaron. 2005. 'Politeness in Thai Computer-Mediated Communication.' In: Robin T. Lakoff and Sachiko Ide (eds.). Broadening the Horizon of Linguistic Politeness. Amsterdam. Philadelphia: John Benjamins Publishing Company, pp. 145162.

Kummer, Manfred. 1992. 'Politeness in Thai.' In Richard J. Watts, Sachiko Ide and Konrad Ehlich (eds.), Politeness in Language: Studies in its History, Theory, and Practice. New York: Mouton de Gruyter, pp 326-336.

Lakoff, Robin T. 1976. Language and Woman's Place. New York: Octagon Books.

Lakoff, Robin T. and Sachiko Ide. (eds.). 2005. Broadening the Horizon of Linguistic Politeness. Amsterdam and Philadelphia: John Benjamins Publishing Company.

Mahmud, Murni. 2008a. Politeness in Bugis. A Thesis. Canberra, Australia: The Australian National University.

Mahmud, Murni. 2008b. 'Speaking Bugis and Speaking Indonesian in Bugis Society'. RIMA (Review of Indonesia and Malay Affairs), Volume 42, number 22008.

Meier, A. J. (1995). 'Passages of Politeness', Journal of Pragmatics, 24: 381-392.

Mizutani, Ozamu, and Nobuko Mizutani. 1987. How to be Polite in Japanese. Tokyo, Japan: The Japan Times, Ltd.

Pelras, Christian. 1996. The Bugis. Cambridge, Massachussets: Blackwell Publishers.

Pizziconi, Barbara. 2003. 'Re-examining Politeness, Face, and the Japanese Language'. Journal of Pragmatics, 35: 1471-1506.

Scupin, Raymond. 1988. 'Language, Hierarchy, and Hegemony: Thai Muslim Discourse Strategies'. Language Sciences, 10(2): 331-351.

Sneddon, James. 1994. Indonesian Reference Grammar. Australia: Allen \& Unwin.

Watts, Richard J. 1992. 'Linguistic Politeness and Politic Verbal Behaviour: Reconsidering Claims for Universality.' In Richard J. Watts, Sachiko Ide and Konrad Ehlich (eds.). Politeness in Language: Studies in Its History, Theory, and Practice. New York: Mouton de Gruyter, pp 43-69.

Zhan, Kaidi. 1992. The Strategies of Politeness in the Chinese Language. California, USA: The Regents of the University of California. 